\title{
The Implementation of Soft System Methodology (SSM) for Systems Development in Organizations (Study Case: The Development of Tourism Information System in Palembang City)
}

\author{
Sandfreni ${ }^{1}$, Fransiskus Adikara $^{2}$ \\ $\left\{\right.$ sandfreni@esaunggul.ac.id ${ }^{1}$, fransiskus.adikara@esaunggul.ac.id $\left.{ }^{2}\right\}$ \\ Fakultas Ilmu Komputer, Sistem Informasi, Universitas Esa Unggul, Jakarta 11510, Indonesia ${ }^{1,2}$
}

\begin{abstract}
Nowadays the massive improvement in Information Technology, which integrates computer technology and telecommunication, has lead to revolution in the field of Information System. The positive momentum in the world of information technology that is indicated by the rapid growth of Internet usage should become a positive enablement in the development of tourism industry. The implementation of information technology could help the tourist in finding the information about tourist attractions, its facilities, route, distance, cost required to get there. Soft Systems Management (SSM) is one of the best options that can be used to support and define the tourism information system (e-tourism). The SSM defined system is expected to meet the system stakeholder requirements, such that give optimum value to the tourist and help the country to attract more tourists visiting the Indonesia.
\end{abstract}

Keywords: SSM, Tourism, Information System, Development, Palembang

\section{Introduction}

The World of Touris mis one of the foreign exchange-producing sectors that has considerable potential to be developed. If the touris ms ector is well developed and managed it will make a large contribution to the country's finances. Undang-Undang(UU) No. 9 of 1990 states that touris mis everything related to touris m, including the exploitation of tourist objects and attractions as well as other businesses related to the field. The types of businessin the field of touris minclude several types of businesses including the types of businesses providing accommodation, providing food and beverages, providing tourist transportation, providing tourist facilities and tourism areas.

The development of the tourism sector will also have an impact on improving the welfare of the community, the real economic sector in society such as crafts, various foods, lodging, hotels and so on can dev elop, with the rise of the real economic sector will be able to increase the degree of community life both clothing, food, board, education and health. The amount of government support for the development of the tourism industry can accelerate the acceleration of the progress of the world of tourism in Indonesia. Through collaboration between the Minis try ofCulture and Touris mand the Ministry of Communication and Information, the promotion of the tourism potential of Palembang city can be disseminated to the wider community both nationally and internationally, thereforeadvances in information and communication technology are very possible to be used as a means of promoting Indonesian touris m throughout the world.

In this era the media used to promote tourism is more than the previous period. The progress of information technology is one of the driving factors. This technology has been widely adopted by government, education, businessand others as a means of promotion, dissemination of information and transactions, therefore the terms emerge as e-government, e-learning, e-business, e-commerce etc.

The world of tourism, which is one of the fields cultivated by the government, is the time to utilize Information Technology as an implementation in e-government to publicize and market regional tourism potential. By utilizing Information Technology means the existence of a Management Information Systembased on electronic data processing. However, in fact there are still many obstacles faced in the application of Information Technology including the limited human resources that are reliable in this field who are able to manage, utilize and develop information technology in tourism, the function of Information Technology for data processing and complex transactions and the provision of information for the public is still very limited, sometimes there are still reluctance of some bureaucrats to open access to the public even though the data and information is intended for public consumption.

As economic growth and community welfare increase, the need for a vacation is increasing so that information is needed about tourist destinations, attractive tourist attractions, available facilities such as transportation, tourismproducts and so on, however often tourists or potential tourists both local and foreign have difficulty to obtain this information because they do not know where and from whom information can be obtained. Therefore information in the field of touris mneeds to be prepared properly and structured so that the public can access easily. In addition, Indonesia als o does not yet have a software that can help plan touris $m$ trips bas ed on certain conditions, for example, the budget owned by tourists and tourist criteria desired by tourists. With a number of phenomena like this, of course it will have an impact on the growth of touris m in the city of 
Palembang which should have the potential to develop rapidly. Besides that, especially for ordinary tourists who really need such information and services, they will als o find it difficult. As a comparison, Singapore in marketing its touris mobjects has utilized information technology well, the Singapore government through the InfocommDevelopment Authority(IDA) has established cooperation with the Singapore Tourism Board (STB) which is named Digital Concierge. Through Concierge, tourists will be served with handy and location-based pers onal services, they will als o obtain various information such as interesting attractions around the location where the touris ts are located, the information can be accessed through various mobile devices such as phones.

Based on the background, the res earchers applied the Soft SystemMethodology (SSM) method to be able to provide touris tinformation for touris ts with the development of the TourismInformation System in Palembang. The goal with this systemis that tourists can easily obtain in formation that can attract tourists to come and take a vacation to the city of Palembang. From the res earch conducted then get the results of the analy sis in accordance with the stages applied to the SSM method that can be used to improve the system or developing an existing tourism information system.

\section{Research Methodology}

Soft SystemMethodology (SSM) is a technique for analyzing and finding solutions to human activity systems developed by Peter Checkland (1999) and Brian Wilson (2001) through "action research". Soft system methodology is perfect for res earch whose main purpose is to conceptualize models, improve pragmatic actions, seek compromise, as well as joint and participatory learning such as clas sroom action res earch, organizational development, and community development. Soft System Methodology is a methodology used to support the structuring of thinking in complexorganizational and community problems. With regard to this problem, soft systemmethodology is the process of identifying, formulating the root of the problemand solving it, finding and bringing together the opinions of the parties involved such as implementers, decision makers, users, and taking into account environmental conditions and general views of society / politics / social culture. Soft system methodology treats individuals as organizational units or communities that have differences and similarities.

Soft systemmethodology assumes that each individualwill see the world differently. Different world views certainly lead to varied understanding and evaluation of any situation, which leads in turn to different ideas for positive action. Ideas do not always contradict each other (generally there is likely to be some overlap), but they may differ enough to make a difference in seriou s problems when deciding on an action. The basic model of soft systemmethodology is the seven-stagemodel. The whole process of soft systemmethodology is the process of mutuallearning: practitioners learn about organizations; Organizational members learn about the diversity of views and in their organizations, and about their peers. In SSM the method used is a process involving the environment with relevant relationships between the real world and the conceptual model produced by the sys tem, with the hope of finding and defining problems that provide alternative changes. There are seven steps in implementing SSM, as shown in Figure 1.

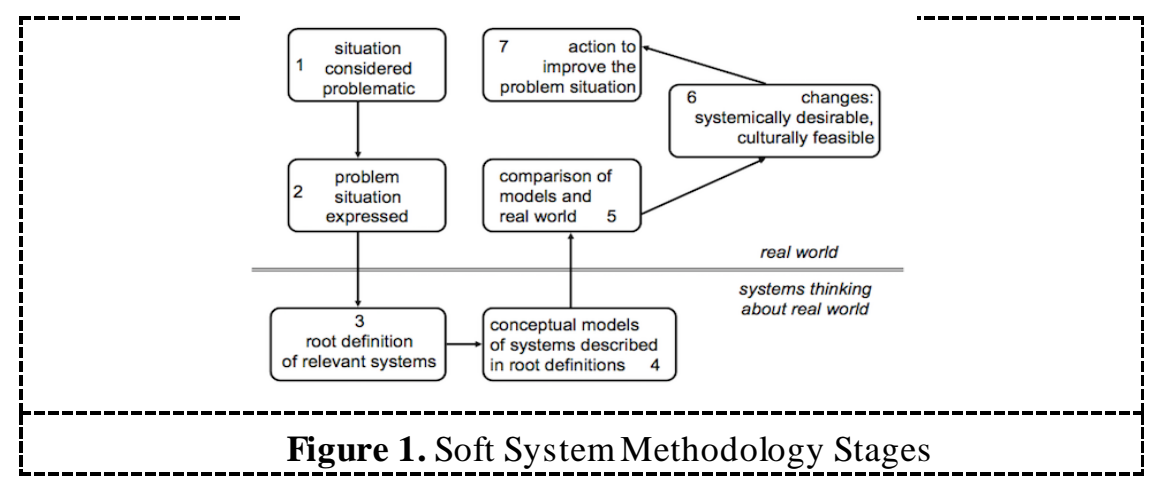

With the explanation as follows:

\section{Situation Considered Problematic}

This stage aims to find out and define the situation and problems to be discussed, because the ultimate goal of the SSM itself is problemsolving. At this stage information will be collected about the structure and process through research, data collection, and through indirect interviews to find the main problems that occur. 


\section{Problem Situation Expressed}

This stage uses the rich picture aims to represent the current situation, problems that arise, existing conflicts, and the interests of each section.

3. Root definition of relevant system

This stage explains the problems that exist in the formof words. The purpose of the root definition is to look for what will be done, why it must be done, who is doing it, who is at a disadvantage or profit from existing problems and what environmental influences are limiting actions and activities to be carried out. An extension of the problem can be found using the CATWOE method. CATWOE consists of:

- Customer (C)

It is a person who expects the benefits of the actions taken

- $\operatorname{Actor}(\mathrm{A})$

Person who took the action

- Transformation Process $(\mathrm{T})$

The changes from existing input to a better direction

- Weltanschauung (W)

An ideal form of action to deal with and observe problems

- Owner (O)

An actor who can stop action

- Environmental Constraint (E)

An obstacle in the action environment

4. Conceptual Models of systems describe in root definitions

This stage describes the flow and dependence of activities that have previously been defined and described in the root definition. Conceptualmodels are created using words that will later be needed to describe the activities that must be carried out in defining the problem.

At this stage also a measurement model that includes :

- Efficacy

The methods that used in the service to produce the desired output.

- Efficiency

A measure of the accuracy of the objectives (effectiveness) of a process or activity carried out. Efficiency can be seen from several variables such as, low cost and time spent in achieving maximum results from existing inputs.

- Effectiveness

Appropriate (regarding the target), how much level of benefits can be provided by the use of IT resources that have been invested in the overall performance of the company's operations.

5. Comparison of models and real world

This stage compares the recommended model given by the system with real world conditions.

6. Change: Systemically Desireble, Culturally Feasible

This stage makes changes thatmight occur if the model recommendations given by the system are run. All comparisons between real systems and conceptual models will be compared, which things will be changed or not.

7. Action to Improve the Proble Situation

This stage describes the implementation or what actions might be carried out as a solution to the problem.

Initially, the SSM approach was seen as an ordinary modeling tool, but after development, the approach has improved as a learning tool and a development tool as an aid in interpreting problems. SSM is a methodology for analyzing and modeling systems that integrate technology (hard) systems and human (soft) systems. SSM is an approach to modeling processes within an organization and its environment and is often used for modeling change management, where the learning organization itself is change management.

\section{Discussion}

Touris mis a temporary movement carried out by humans with the aimof getting out of routine work, out of his residence. Activities are carried out during their stay at the destination and facilities are made to meet their needs. Tourism lesson is a lesson to get out of the usual situation and this is influenced by the economic, 
physical and social welfare of touris ts who will carry out touris m activities. Expectations and adjustments are made by residents who receive them and there is a role of intermediaries and travel management agencies acting as intermediaries between tourists and residents in the tourist destination. (Happy Marpaung, 2002: 13). Tourism development can be done by improving or improving the quality of tourist objects or areas by improving facilities and infrastructure as well as improving services in terms of accommodation and transportation and carried out in a structured, orderly and in an integrated system between components of touris m development. Also important in terms of tourism development is the promotion system in the sale and imaging of a tourist destination, touris tattraction and tourist area. The constraints of developing national touris mat this time are that there are still many areas that have not been able to manage touris mpotentials well and the touris mmanagement patterns are still conventional so that the management system and information system of sales potential for touris $m$ are not yet able to run well and sometimes unable to compete with the region travel in neighboring countries. Current advances in information technology and the high use of the internet today should be put to good use in terms of managing tourisminformation so that potential tourists can easily access information about a tourist destination, region or tourist attraction along with all supporting facilities and infrastructure and tour packages offered and the cost and length of time that will be used for travel.

Optimization of tourism potential is not only in the direction of revamping the location and attractions, but must be followed by the use of internet technology in conducting promotions as well as choosing tour packages and booking directly by tourists. The use of information technology is believed to be a very influential factor for the development of the tourism sector. Information about a tourist destination along with facilities and infrastructure as well as other components related to tourism are very much needed by potential tourists in determining the tourist destination. Information can be defined as datathat has been proces sed into a form that has meaning for the recipient. MediumInformation system is a system that has the ability to collect information from all sources and use various media to dis play that information. Even this information systemis supportedby the availability of information technology, information technology according to Lucas (2000), is any form of technology applied to process and transmit information in electronic form.

Utilization of information technology in tourismdevelopment is carried out by inputting data about tourist objects, hotels and lodging around tourist sites, modes that can be used to access locations, events that are often held, cultural uniqueness and local traditions in tourist areas and maps distribution of tourism objects accompanied by instructions on travel routes. The results of this data analys is with all the details are then informed to prospective tourists who are applied in the form of a package of tourist activities. Utilization of information systems in one tourisminformation system must also provide space to in teract between touris ts and touris m service providers s o that the ease of this interaction will facilitate trans actions between the two parties.

At present, the presentation of information about touris mby using the use of information technology is increasing and tourismneeds are als o higher so that the tourisms ector has the opportunity to attract the attention of local and foreign touris ts to visit variou s tours in the city of Palembang. Soft Systems Management (SSM) is a technique that can be used to increase the number of tourists visiting the city of Palembang that can provide benefits for the foreign exchange of the city of Palembang.

Case studies used in the application of some of the techniques described above are attracting local and foreign touris ts to Palembang city attractions.

From the explanation above, the seven stages of SSM can be implemented, i.e :

\section{Stage 1 Situation Considered Problematic}

This stage aims to find out and define the situation and is sues to be discussed. These problems include:

- Lack of information provided by thePalembang city tourism department to local and foreign touris ts through various media, es pecially media that use information technology, so that touris ts do not know what touris mis in the city of Palembang.

- Budgeting problems have always been a major obstacle in preparing touris m data using Information Technology.

- Not yet computerized, all touris mactivities that can hamper the process of touris m data collection are very dynamic so that they need careful handling.

\section{Stage 2: Problem Situation Expressed}

This stage uses rich picture that aims to represent the current situation, problems that arise, existing conflicts, and the interests of each section. Figure III-1 is a rich picture of a case study raised in this paper.

From Figure 2 it is illustrated that there are still some problems between actors:

- Palembang Government Tourism Office 
The Tourism Office needs a system that can help them in presenting information, requires a budget to implement information technology and the process of upadating the data on tourismactivities

- Tourist

Tourists need detailed information about tourism in the city of Palembang.

Stage 3 Root Definition of Relevant Systems

This stage explains theproblemand also extends the problemusing the CATWOE method. The root definition of this case study is as follows:

Application of Information Technology by using Soft System Methodology (SSM) in developing the Palembang city touris msystemthrough the Palembang City Tourism Office, so as to facilitate localtourists The application for permission to open tenans at shopping centers is a service that is owned by the company's management to facilitate requests in producing letters permit for opening tenants by using the role of department staff (fit out department, engineering department, financial and accounting department) and management in examining and approving permits for opening tenants with discipline from the applicant in providing administrative requirements and completeness of payment. 


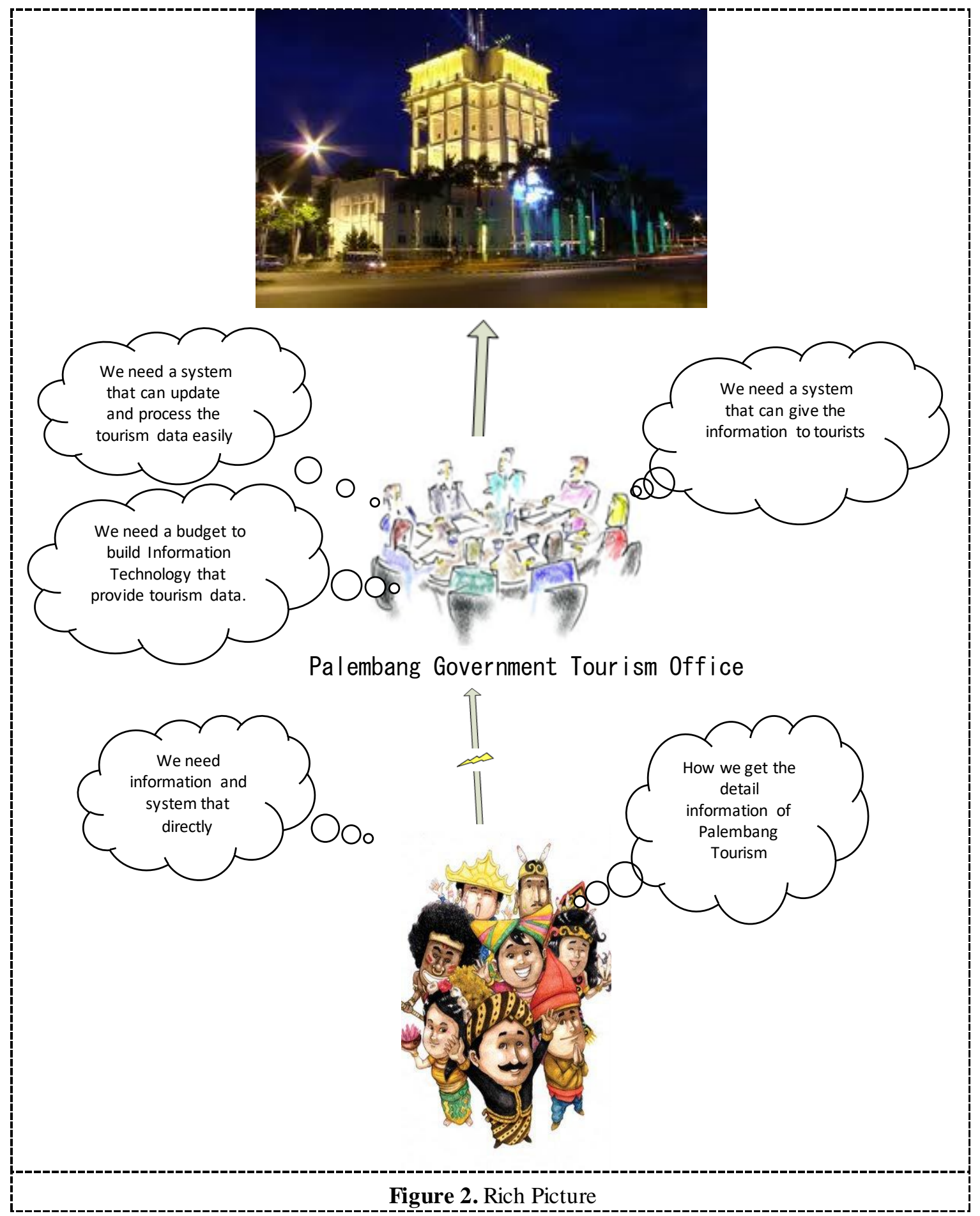

And the CATWOE method of this case study is as follows :

- Customer (C)

Local and foreign tourist

- $\operatorname{Actor}(\mathrm{A})$

Palembang government tourism office, local tourist and foreign tourist

- Transformation Process (T)

Updating tourism activity in Palembang city $\rightarrow$ Detail Information of tourism in Palembang city

- Weltanschauung (W)

Getting detail information about tourism in Palembang city 
- Owner (O)

Palembang government touris m office

- Environmental Constraint (E)

Tourist attraction, culture, art, food from Plamebang City

Stage 4 Conceptual Models of System Described in Root Definition

This stage describes each definition made a diagram in the form of activity model diagrams. The flows and dependences of activities that have previously been defined and described in the root definition (Figure 3).

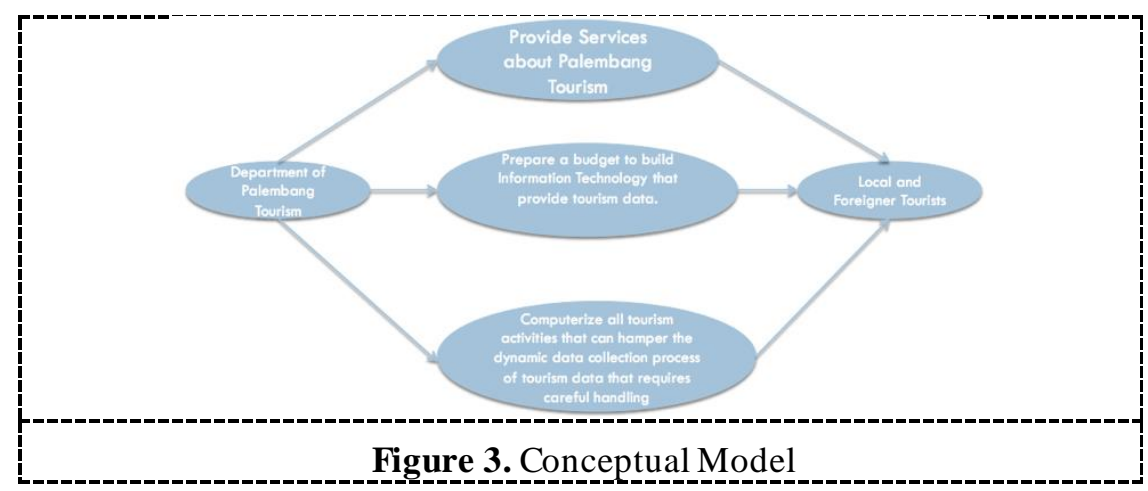

At this stage also a measurement model that includes:

- Efficacy

The methods used in providing detailed information on Palembang city tourismcan produce the desired output.

- Efficiency

- Efficient use of resources in providing detailed information about Palembang city touris m is minimal due to the lack of budget funds prepared by the Palembang City Tourism Office, existing SOPs are still lacking

- Effectiveness

The output produced is in accordance with tourist demand, but the level of effectiveness is still low because sometimes it does not do upadating data on tourismactivities.

Stage 5 Comparison of models with the real world

This stage compares the recommended model given by the system with real world conditions. In Table 1 the comparison of each process from the conceptual model to the real world will be explained.

Table 1. Comparis on of models with the real world

\begin{tabular}{|c|c|c|}
\hline Activity & Real World & Recommendations \\
\hline $\begin{array}{l}\text { Implementing } \\
\text { Touris m } \\
\text { Technology by } \\
\text { Palembang } \\
\text { Government } \\
\text { Touris mOffice. }\end{array}$ & $\begin{array}{l}\text { Palembang TourismOffice implements } \\
\text { the Information Technology in } \\
\text { presenting Palembang city tourism } \\
\text { information, but sometimes the tourism } \\
\text { office lacks of the resources to operate } \\
\text { the information technology. }\end{array}$ & $\begin{array}{l}\text { Palembang Tourism Office should conduct } \\
\text { training for its staff so that, they can } \\
\text { operate and access information } \\
\text { technology. }\end{array}$ \\
\hline $\begin{array}{l}\text { The process of } \\
\text { updating tourism } \\
\text { data (tourism } \\
\text { objects, culture, } \\
\text { handicrafts and } \\
\text { special food) of } \\
\text { Palembang city } \\
\text { through the } \\
\text { Palembang tourism } \\
\text { office. }\end{array}$ & $\begin{array}{l}\text { Palembang TourismOffice does not } \\
\text { carry out an informative data collection } \\
\text { process that can provideinformation to } \\
\text { tourists through information technology } \\
\text { media. }\end{array}$ & $\begin{array}{l}\text { Palembang TourismOffice must prepare a } \\
\text { budget to support information technology } \\
\text { activities so that through thesemedia } \\
\text { tourists know the latest information about } \\
\text { Palembang city tourism. }\end{array}$ \\
\hline
\end{tabular}




\begin{tabular}{|l|l|l|}
\hline & & \\
\hline $\begin{array}{l}\text { Palembang Tourism } \\
\text { Office made a e- } \\
\text { touris mregarding } \\
\begin{array}{l}\text { Palembang city } \\
\text { tourism }\end{array}\end{array}$ & $\begin{array}{l}\text { Palembang TourismOffice does nothave } \\
\text { a special website and special software } \\
\text { about Palembang city touris } \mathrm{m}\end{array}$ & $\begin{array}{l}\text { The Department of Touris ms hould utilize } \\
\text { information technology by creating a } \\
\text { special website and e-tourismabout } \\
\text { Palembang city. }\end{array}$ \\
\hline $\begin{array}{l}\text { Palembang Tourism } \\
\begin{array}{l}\text { Office provides } \\
\text { information } \\
\text { services to local } \\
\text { and foreign tourists. }\end{array}\end{array}$ & $\begin{array}{l}\text { This process is one of the main processes } \\
\text { in attracting the attention of tourists. The } \\
\text { obs tacle that may occur in this process is } \\
\text { the unavailability of information services } \\
\text { from the Palembang TourismOffice. }\end{array}$ & $\begin{array}{l}\text { To overcome these obstacles, the } \\
\text { Palembang Tourism Office should be } \\
\text { provide the services to make it easier for } \\
\text { touris ts to know about Palembang city } \\
\text { attractions. }\end{array}$ \\
\hline
\end{tabular}

Stage 6 Changes: Systemically Desirable, Cultural Feasible

This stage makes changes that might occur if the model recommendations given by the system are run. All comparisons between real systems and conceptual models will be compared, which things will be changed or not.

$>$ Cultural Changes

Changes made in this section are:

- Training in the use of service s ystemapplication s correctly

- Discipline staff to better understand and comply with existing SOPs

$>$ System Changes

System modification for adopting real situation in every aspect.

Stage 7 Application of the model in the real world

This stage describes theimplementation or what actions might be carried out as a solution to the problem. Actions that might be taken as a solution to the problemnamely:

- Develop standard operational procedurefor every provided service

- Develop systeminformation management:

- Tourism Staff: provide information to the tourist, as central storage for recording all touris mactivity

o Tourist: Getting the information about tourist attraction, culture, art and food related to the tourist destination.

\section{Conclusion}

From the explanation and discussion in this study, it can be concluded that the advancement of information technology in the tourism sector is one of them by implementing information systems in every process of information services provided by the Palembang City Tourism Office. Information systems that contain an integrated set of computerized components aimto collect data, store data, process data, and produce information. The information systemcan reflect and observeactions in the operating system by proces sing, recording, and reporting operational transactions and can also support managerial activities, in cluding making management decisions.

In addition, this study also looks at how the application of information technology using Soft System Methodology (SSM) is an effective approach to support Palembang's touris m activities in identifying problems and developing information systems.

The next research that can be done is to apply the results of the analysis stages of the Soft System Methodology method and use the final results as a basis for designing the next tourisminformation system. Furthermore, the results of the design can be used to build the system until the system is complete and can be implemented.

\section{References}

[1] Adrian Small, David Wainwright (2013), "SSM and technology management: Developing multimethodology through practice" European Journal of Operational Research, ISSN 0377-2217.

[2] Wenbin B. Liu, Wei Meng, John Mingers, Ning Tang, Wei Wang (2012), "Developing a performance management system using soft systems methodology: A Chinese case study", European Journal of Operational Research, Volume 223, Pages 529-540, ISSN 0377-2217. 
[3] Philippe Vandenbroeck, Rachel Dechenne, Kim Becher, Marijke Eyssen, Koen Van den Heede (2013), "Recommendations for the organization of mental health services for children and adolescents in Belgium: Use of the soft systems methodology", ISSN 0168-8510.

[4] Mehregan, M. Reza, Mahnaz Hosseinzadeh, and Aliyeh Kazemi (2012), "An application of Soft System Methodology", Social and Behavioral Sciences, 41, pp.426-433

[5] Checkland P. Systems Thinking, Systems Practice, 1999, Wiley, ISBN 0-471-98606-2

[6] Wilson B. Soft Systems Methodology Conceptual Model Building and its Contribution, 2001, Wiley ISBN0 -47189489-3

[7] Miller G.A. “The Psychology of Communication” 1970, Pelican books, 140211411

[8] Forbes, P. and Checkland, P.B. (1987). 'Monitoring and control in systems models', Internal Discussion Paper 3/87, Department of Systems, University of Lancaster

[9] Undang-Undang Republik Indonesia Nomor 10.Tahun 2009. Tentang Kepariwisataan

[10] Marpaung. (2002). Pengetahuan Kepariwisataan. Bandung: Alfabeta.

[11] Lucas, G.F. 2000. Information Technology for Management. McGraw-Hill 